\title{
Clinicopathological Significance of BRAF V600E Mutation in Egyptian Colorectal Cancer Patients
}

\author{
MONA A. KORA, M.Sc.*; NANSY Y. ASAAD, M.D.*; HALA S. EL-REBEY, M.D.*; \\ RANIA A. HASSANIN, M.D.* and ALSHIMAA M. ALHANAFY, M.D.** \\ The Departments of Pathology* and Oncology and Nuclear Medicine**, Faculties of Medicine, Menoufia University
}

\begin{abstract}
Background: In Egypt, there is a rapid increase in Colorectal Cancer (CRC) incidence with more aggressive course and younger age at presentation compared to western patients.

Aim of Study: This study aimed to examine BRAF V600E mutation in Egyptian CRC patients.

Material and Methods: This study is done by collaboration between Pathology and Clinical Oncology \& Nuclear Medicine Departments, Faculty of Medicine, Menoufia University between January 2015 and August 2019 in which 81 CRC patients were studied. Expression of BRAF V600E protein was evaluated by immunohistochemistry. The results of the studied marker were correlated with different clinicopathological parameters and survival data.

Results: The frequency of BRAF V600E mutation was $51.9 \%$. There was no statistical difference between different studied clinicopathological parameters including sidedness and BRAF V600E mutation. Regarding survival during this follow-up duration, no significant statistical differences were detected.

Conclusion: In Egyptian CRC patients, BRAF V600E protein expression had no correlation with $\mathrm{CRC}$ prognosis.

However, validation of our results in a larger sample size is necessary.
\end{abstract}

Key Words: Egyptian colorectal cancer - BRAF V600E Protein expression - Prognosis.

\section{Introduction}

IN Egypt, gastrointestinal tract tumors constitutes $18.54 \%$ of all malignancies received in Pathology Department at National Cancer Institute (NCI) during the years 2000 and 2011. They are the second common malignancy in Egypt after breast cancer. Colorectal Cancer (CRC) represent 35\% of all gastrointestinal tract tumors [1].

Correspondence to: Dr. Mona A. Kora, The Department of Pathology, Faculty of Medicine, Menoufia University
Colorectal cancer is the third most common cancer worldwide and its incidence is still increasing annually [2].

Colorectal cancer is a heterogeneous disease which has variable clinical, pathological, and molecular features [3]. However, the diversity of the disease has made it difficult to accurately classify and treat CRC patients [4]

Defining colorectal cancer molecular subtypes based upon pathway-driven alterations has a potential in segrgation of patients into groups having different prognosis and guide targeted therapy [5]

Despite the progress that has been made towards the identification of the molecular mechanisms involved in CRC, currently there are many unclear points [6]. Two pathways of colorectal tumorigenesis include Microsatellite Instability (MSI) and chromosomal instability have been described [5]

Chromosomal instability reflects a separate mechanism of colorectal cancer carcinogenesis. Tumors with chromosomal instability have chromosomal gains and losses, with or without structural rearrangements, possibly reflecting an increased mutation rate and occurs in around 60\% of CRC cases [6].

V-rafmurine sarcoma viral oncogene homolog $\mathrm{B}$ (BRAF) encodes a serine/threonine protein kinase, a downstream effector of the KRAS protein. Activating BRAF mutations occur in approximately 4\%-20\% CRCs [7]. Most frequent activating mutations of BRAF found in colorectal cancer almost invariably result in valine substituting glutamate at residue 600 (BRAF V600E), accounts for approximately $90 \%$ of BRAF mutations [8] and occur at a frequency of $10-15 \%$ [9]. 
The relationship between BRAF V600E mutation and the clinicopathological characteristics of CRC remains limited [10]. Although some previous studies have shown that BRAF V600E mutations confer poorer prognosis in CRC [11], others have not [12]

The status of BRAF V600E is evaluated using molecular technologies after genomic tumoral DNA extraction [13]. Immunohistochemical detection of BRAF V600E mutations would appear to be an attractive alternative for molecular technologies due to the high cost of equipment and reagents for molecular pathology.

The aim of this study was to examine correlation between BRAF V600E mutation and different studied clinicopathological parameters and survival data in Egyptian CRC patients.

\section{Material and Methods}

A retrospective study comprised formalin-fixed, paraffin-embedded blocks of tissues from patients with colorectal cancer retrieved from the archives of Pathology Department, Menoufia Faculty of Medicine, Menoufia University. A total of 81 specimens of colorectal cancer were selected according to the availability of paraffin blocks, clinical and follow-up data. The cases received treatment in Menoufia Cancer Institute during the period between January 2015 and August 2019. Staging was carried out according to TNM staging system of the American Joint Committee on Cancer (AJCC) [14] .

From each block, two sections of 4 micron thickness were obtained. One section was stained by Hematoxylin and Eosin ( $\mathrm{H} \& \mathrm{E}$ ) for reviewing and to evaluate different studied histopathological parameters.

Other section was mounted on positively charged slide, immunohistochemically stained with antibody against BRAF V600E.

\section{Immunohistochemistry:}

Immunohistochemical staining of sections mounted on positive charged glass slides were performed as described elsewhere [15]. The method used for immunostaining was Streptavidin-Biotin staining method. Sections were incubated overnight at $4^{\circ} \mathrm{C}$ with mouse monoclonal anti BRAF V600E antibody (abcam, USA) at 1:100 dilution. Diffuse Uniform granular cytoplasmic expression in malignant melanoma was used as a positive control for BRAF V600E. Rabbit IgG isotype (Sigma Aldrich, USA) was used instead of primary anti- body in the immunohistochemical technique on tissue sections as negative control.

Interpretation of BRAF V600E immunohistochemical staining:

All available tissue sections were assessed for expression of BRAF V600E protein. Cases were considered having positive BRAF V600E protein expression (mutant) if unequivocal diffuse uniform granular cytoplasmic staining of moderate or strong intensity in $\geq 80 \%$ of malignant cells.

Cases were diagnosed as negative for BRAF V600E immnuostaining (wild) if no or week cytoplasmic non granular, non uniform brown staining was observed in malignant cells [16]

\section{Statistical methods:}

The $\chi^{2}$ test was used to assess the relationships between BRAF V600E expression and different clinicopathological parameters. The overall survival were calculated from the date of diagnosis of the primary tumor till the date of last follow-up, death or drop out. The student $(t)$ test was used to assess survival then data were confirmed by Kaplan Meier survival curves to differentiate survival between compared groups using the log rank test. All $p$ values were two-sided, and $p<0.05$ was considered to be significant [17]. Statistical analyses were performed using SPSS 21.00 software.

\section{Results}

The studied cases included 81 colorectal cancer patients. Two cases $(2.5 \%)$ were incisional biopsies while $79(97.5 \%)$ were totally resected (colectomy specimens). The age of cases ranged between 30 and 85 years with a median of 58 years and a mean \pm SD of $56.58 \pm 12.27$. Forty eight out of 81 cases $(59.3 \%)$ were $\leq 58$ years. Thirty three cases $(40.7 \%)$ were males and the other 48 cases $(59.3 \%)$ were females. Majority of cases (55.6\%) had tumor located in distal colon in comparison to $37 \%$ which had tumor located in proximal colon and $7.4 \%$ located in rectum. Thirteen out of 81 cases were arising on top of adenoma while the remaining 68 cases weren't. Gross morphology of $61.7 \%$ were of fungating type, while $12.3 \%$ of cases were of ulcerative type and $25.9 \%$ were of infiltrative type. Sixteen out of 81 cases were of mucinous adenocarcinoma variant while the remaining 65 cases were adenocarcinoma, NOS. Five cases $(6.2 \%)$ were well differnitiated (G1), 54 (66.7\%) were moderately differnitiated (G2) and 22 cases $(27.2 \%)$ were poorly differnitated (G3).

According to the depth of invasion (data were available for 79 colectomy specimens), 8/79 
$(10.1 \%)$ of cases showed pT2 (tumor invade muscularis propria), $48 / 79$ cases $(60.8 \%)$ were with pT3 (tumor invade adventitia) and 23/79 cases $(29.1 \%)$ showed gross perforation or invasion up to adjacent structure (pT4).

Thirty five out of 79 cases $(44.31 \%)$ had lymph node metastasis (data were available for 79 colectomy specimens) and twenty two cases (39.3\%) were associated with distant metastasis (data were available for 56 cases). Five cases out of $81(6.2 \%)$ were of stage group I, 33/81 (40.7\%) were of stage group II while stage group III constituted 22/81 $(27.2 \%)$ and stage group IV constituted $21 / 81$ (25.9\%) (data were available for all cases as the two incisional biopsy cases were M1). Thirty eight out of 81 cases (46.9\%) were of Dueks' B, 21/81 (25.9\%) were of Dueks' C and 22/81 (27.2\%) were of dueks' D (data were available for all cases as the two incisional biopsy cases were M1).

Necrosis was present in 25 out of $81 \mathrm{CRC}$ cases $(30.9 \%)$. Ninteen out of 81 of the cases $(23.5 \%)$ showed Lymphovascular Invasion (LVI). Fifteen out of 81 of the cases (18.5\%) showed perineural invasion.

Data about survival were available for 62 out of the studied 81 cases. Mean \pm SD of overall survival time was $15.89 \pm 10.98$ months. Thirty five out of the available 62 cases died.

\section{BRAF V600E immunostaining results:}

BRAF V600E mutation was detected in $42 / 81$ (51.9\%) of studied colorectal cancer cases while the remaining cases $39 / 81$ (48.1\%) were wild Fig. (1).

Correlation of wild and mutant BRAF V600E colorectal cancer cases with different clinicopathological parametrs were clarified in (Table 1) and survival data (Table 2).

Unfortunately, no significant difference was noted between wild and mutant BRAF V600E colorectal cancer cases with any of clinicopathological variables or survival data $(p>.05)$.
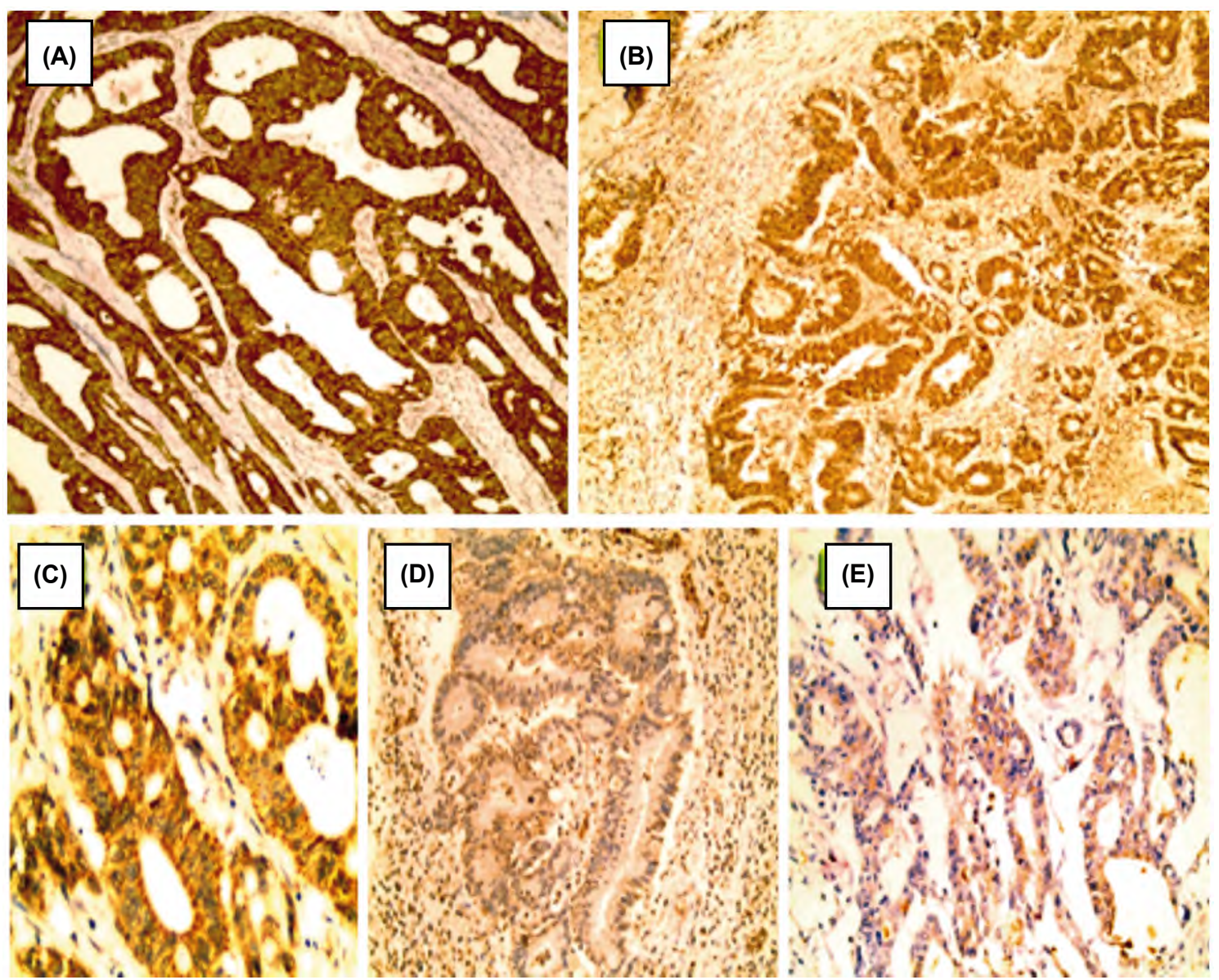

Fig. (1): A- Colorectal carcinoma case with strong positive uniform granular cytoplasmic staining $>80 \%$ of tumor cells for BRAF V600E IHC considered as mutant. B- Another case with strong positive granular cytoplasmic staining considered as mutant. C-Colorectal carcinoma case with moderate positive uniform granular cytoplasmic staining $>80 \%$ of tumor cells for BRAF V600E IHC considered as mutant. D- Another case with mild cytoplasmic staining for BRAF V600E IHC considered as wild E- Colorectal carcinoma case with mild heterogenous cytoplasmic staining for BRAF V600E IHC considered as wild. (IHC X100 for all). 
Table (1): Differences between wild and mutant BRAF V600E colorectal cancer cases regarding clinicopathological variables $(n=81)$.

\begin{tabular}{|c|c|c|c|c|c|c|c|}
\hline \multirow{3}{*}{ Variable } & \multicolumn{4}{|c|}{ Colorectal cancer cases } & \multirow{3}{*}{ Total } & \multirow{3}{*}{$\begin{array}{l}\text { Test of } \\
\text { Sig. }\end{array}$} & \multirow{3}{*}{$\begin{array}{c}p- \\
\text { value }\end{array}$} \\
\hline & \multicolumn{2}{|c|}{$\begin{array}{l}\text { Wild BRAF V600E } \\
n=39\end{array}$} & \multicolumn{2}{|c|}{$\begin{array}{l}\text { Mutant BRAF V600E } \\
n=42\end{array}$} & & & \\
\hline & No. & $\%$ & No. & $\%$ & & & \\
\hline \multicolumn{8}{|c|}{ Clinical data } \\
\hline $\begin{array}{l}\text { Age: } \\
\quad \leq 58 \\
\quad>58\end{array}$ & $\begin{array}{l}22 \\
17\end{array}$ & $\begin{array}{l}45.8 \\
51.5\end{array}$ & $\begin{array}{l}26 \\
16\end{array}$ & $\begin{array}{l}54.20 \\
48.50\end{array}$ & $\begin{array}{l}48 \\
33\end{array}$ & $\chi^{2}=.25$ & $p=.62$ \\
\hline $\begin{array}{l}\text { Sex: } \\
\quad \text { Male } \\
\text { Female }\end{array}$ & $\begin{array}{l}18 \\
21\end{array}$ & $\begin{array}{l}54.50 \\
43.80\end{array}$ & $\begin{array}{l}15 \\
27\end{array}$ & $\begin{array}{l}45.50 \\
56.20\end{array}$ & $\begin{array}{l}33 \\
48\end{array}$ & $\chi^{2}=.91$ & $p=.34$ \\
\hline $\begin{array}{l}\text { Colonic side: } \\
\text { Proximal } \\
\text { Distal } \\
\text { Rectum }\end{array}$ & $\begin{array}{l}14 \\
22 \\
3\end{array}$ & $\begin{array}{l}46.70 \\
48.90 \\
50.00\end{array}$ & $\begin{array}{l}16 \\
23 \\
3\end{array}$ & $\begin{array}{l}53.30 \\
51.10 \\
50.00\end{array}$ & $\begin{array}{l}30 \\
45 \\
6\end{array}$ & $\chi^{2}=.05$ & $p=.98$ \\
\hline $\begin{array}{l}\text { Arising within adenoma: } \\
\text { Yes } \\
\text { No }\end{array}$ & $\begin{array}{l}5 \\
34\end{array}$ & $\begin{array}{l}38.50 \\
50.00\end{array}$ & $\begin{array}{l}8 \\
34\end{array}$ & $\begin{array}{l}61.50 \\
50.00\end{array}$ & $\begin{array}{l}13 \\
68\end{array}$ & $\chi^{2}=.58$ & $p=.45$ \\
\hline $\begin{array}{l}\text { Gross description: } \\
\text { Fungating mass } \\
\text { Malignant ulcer } \\
\text { Infiltrating mass }\end{array}$ & $\begin{array}{l}28 \\
4 \\
7\end{array}$ & $\begin{array}{l}56 \\
40 \\
33.3\end{array}$ & $\begin{array}{l}22 \\
6 \\
14\end{array}$ & $\begin{array}{l}44 \\
60 \\
66.7\end{array}$ & $\begin{array}{l}50 \\
10 \\
21\end{array}$ & $\chi^{2}=3.35$ & $p=.19$ \\
\hline Histonathological tyno. & \multicolumn{4}{|c|}{ Histopathological data } & & & \\
\hline $\begin{array}{l}\text { Adenocarcinoma } \\
\text { Mucoid adenocarcinoma }\end{array}$ & $\begin{array}{l}31 \\
8\end{array}$ & $\begin{array}{l}47.70 \\
50.00\end{array}$ & $\begin{array}{l}34 \\
8\end{array}$ & $\begin{array}{l}52.30 \\
50.00\end{array}$ & $\begin{array}{l}65 \\
16\end{array}$ & $\chi^{2}=.03$ & $p=.87$ \\
\hline $\begin{array}{l}\text { Grade: } \\
\quad \text { G1 \& G2 } \\
\text { G3 }\end{array}$ & $\begin{array}{l}27 \\
12\end{array}$ & $\begin{array}{l}45.80 \\
54.50\end{array}$ & $\begin{array}{l}32 \\
10\end{array}$ & $\begin{array}{l}54.20 \\
45.50\end{array}$ & $\begin{array}{l}59 \\
22\end{array}$ & $\chi^{2}=.49$ & $p=.48$ \\
\hline $\begin{array}{l}\text { Depth of invasion }(n=79) \text { : } \\
\text { T2 \& T3 } \\
\text { T4 }\end{array}$ & $\begin{array}{l}28 \\
9\end{array}$ & $\begin{array}{l}50.00 \\
39.10\end{array}$ & $\begin{array}{l}28 \\
14\end{array}$ & $\begin{array}{l}50.00 \\
60.90\end{array}$ & $\begin{array}{l}56 \\
23\end{array}$ & $\chi^{2}=.77$ & $p=.38$ \\
\hline $\begin{array}{l}N \text { stage }(n=79) \text { : } \\
\quad \text { N0 } \\
\text { N1 \& N2 }\end{array}$ & $\begin{array}{l}17 \\
20\end{array}$ & $\begin{array}{l}38.60 \\
57.10\end{array}$ & $\begin{array}{l}27 \\
15\end{array}$ & $\begin{array}{l}61.40 \\
42.90\end{array}$ & $\begin{array}{l}44 \\
35\end{array}$ & $\chi^{2}=2.68$ & $p=.1$ \\
\hline $\begin{array}{l}\text { M stage }(n=56) \text { : } \\
\text { M0 } \\
\text { M1 }\end{array}$ & $\begin{array}{l}16 \\
12\end{array}$ & $\begin{array}{l}47.10 \\
54.5\end{array}$ & $\begin{array}{l}18 \\
10\end{array}$ & $\begin{array}{l}52.90 \\
45.50\end{array}$ & $\begin{array}{l}34 \\
22\end{array}$ & $\chi^{2}=.29$ & $p=.58$ \\
\hline $\begin{array}{l}\text { Stage grouping: } \\
\text { I \& II } \\
\text { III \& IV }\end{array}$ & $\begin{array}{l}15 \\
24\end{array}$ & $\begin{array}{l}39.50 \\
55.80\end{array}$ & $\begin{array}{l}23 \\
19\end{array}$ & $\begin{array}{l}60.50 \\
44.20\end{array}$ & $\begin{array}{l}38 \\
43\end{array}$ & $\chi^{2}=2.16$ & $p=.14$ \\
\hline $\begin{array}{l}\text { Dukes' stage: } \\
\text { B } \\
\text { C } \\
\text { D }\end{array}$ & $\begin{array}{l}15 \\
12 \\
12\end{array}$ & $\begin{array}{l}39.5 \\
57.1 \\
54.5\end{array}$ & $\begin{array}{l}23 \\
9 \\
10\end{array}$ & $\begin{array}{l}60.5 \\
42.9 \\
45.5\end{array}$ & $\begin{array}{l}38 \\
21 \\
22\end{array}$ & $\chi^{2}=2.19$ & $p=.34$ \\
\hline $\begin{array}{l}\text { Necrosis: } \\
\text { Present } \\
\text { Absent }\end{array}$ & $\begin{array}{l}12 \\
27\end{array}$ & $\begin{array}{l}48 \\
48.20\end{array}$ & $\begin{array}{l}13 \\
29\end{array}$ & $\begin{array}{l}52 \\
51.80\end{array}$ & $\begin{array}{l}25 \\
56\end{array}$ & $\chi^{2}=.000$ & $p=.99$ \\
\hline $\begin{array}{l}\text { LVI: } \\
\text { Present } \\
\text { Absent }\end{array}$ & $\begin{array}{l}10 \\
29\end{array}$ & $\begin{array}{l}52.60 \\
46.80\end{array}$ & $\begin{array}{l}9 \\
33\end{array}$ & $\begin{array}{l}47.40 \\
53.20\end{array}$ & $\begin{array}{l}19 \\
62\end{array}$ & $\chi^{2}=.20$ & $p=.66$ \\
\hline $\begin{array}{l}\text { Perineural invasion: } \\
\text { Present } \\
\text { Absent }\end{array}$ & $\begin{array}{l}10 \\
29\end{array}$ & $\begin{array}{l}66.7 \\
43.90\end{array}$ & $\begin{array}{l}5 \\
37\end{array}$ & $\begin{array}{l}33.3 \\
56.10\end{array}$ & $\begin{array}{l}15 \\
66\end{array}$ & $\chi^{2}=2.53$ & $p=.11$ \\
\hline $\begin{array}{l}\text { Overall survival }(n=62) \text { : } \\
\quad \text { Mean } \pm \text { SD }\end{array}$ & 15.2 & $\pm 9.29^{\text {Survi }}$ & al data & $16.44 \pm 12.3$ & 62 & $t=.44$ & $p=.67$ \\
\hline
\end{tabular}


Table (2): Univariate overall survival analysis for studied colorectal cancer cases regarding BRAF V600E mutation $(n=62)$.

\begin{tabular}{|c|c|c|c|c|}
\hline Variable & No & $\begin{array}{l}\text { Overall survival } \\
\text { mean }(95 \% \mathrm{CI})\end{array}$ & SE & $\begin{array}{lc}\log & p- \\
\text { rank } & \text { value }\end{array}$ \\
\hline
\end{tabular}

\section{BRAF V600E}

mutation:

\begin{tabular}{llllll} 
Wild & 28 & $19.24(14.35-24.14)$ & 2.49 & 1.56 & .21 \\
Mutant & 34 & $25.38(18.84-31.92)$ & 3.34 & & \\
\hline
\end{tabular}

SE: Standard Error.

\section{Discussion}

In Egypt, gastrointestinal tract tumors are the second common malignancy in Egypt after breast cancer [1]. Colorectal cancer is the third most common cancer diagnosed in both men and women in the United States [2]

Mutation of BRAF is one of the important molecular alternation in CRC patients [10]. The mutation of BRAF V600E oncogene accounts for up to $80 \%$ of all BRAF mutations [18].

Some studies have reported near to complete concordance between immunohistochemically identified BRAF V600E mutant expression and detection of V600E mutation in colon carcinomas with perfect sensitivity (100\%) and specificity (100\%) $[19,20]$. However, other studies concluded that immunohistochemistry with BRAF V600E antibody is not a useful alternative for genotyping in colorectal carcinomas [21].

In this study, BRAF V600E mutation was detected by immunohistochemistry technique in $51.9 \%$ of studied colorectal cancer cases slightly near to Kanik P et al., [22] who detected mutation in $63 \%$ of patients. Comparatively, Lasota et al., [23] detected lower incidence of BRAF V600E mutation (24\%) and Smeby et al., [24] who used PCR technique found BRAF V600E mutation in $16 \%$ of patients.

This study performed on Egyptian patient didn't detect any statistical difference between presence or absence of BRAF V600E mutation and different studied clinicopathological parameters similar to Gir'ldez et al., [25] who detected BRAF V600E mutation by PCR in early onest CRC. Gir'ldez et al., [25] didn't detect any statistical difference except that the the presence of the BRAF V600E mutation was associated with proximal tumor location.

However, many studies demonstrated association of BRAF V600E mutant CRC patients with dismal clinicopathological parameters as rightsided location, lymphovascular invasion, larger tumor size, and higher TNM stage at diagnosis than did patients with BRAF wild type CRC $[\mathbf{1 0 , 2 6 -}$ 28]. Some of these studies used IHC technique [26], others used PCR [28] and others were meta-analysis as $[10,27]$

Koperek et a., [33] also detected that no significant correlation of BRAF V600E expression with clinicopathologic parameters of aggressiveness in papillary thyroid carcinoma such as lymph node metastasis, peritumoral infiltration, or perithyroidal infiltration. Additionally, BRAF V600E protein expression was significantly more common in tumors with tall cell or oncocytic features but was less common in tumors with follicular growth pattern. Diffuse sclerosing, solid and follicular variants did not show the mutated BRAF V600E protein.

Several explanation to our results may include different BRAF V600E mutation assays which affect the accuracy and precision of the pooled estimates [29]. The discordances between IHC and sequencing results for BRAF V600E in colorectal carcinoma may be due to that protein product expression is also influenced by other factors, as regulatory noncoding RNAs and posttranslational modifications, thereby providing a biologic, rather than a purely methodologic, explanation of some of those discordances [30].

Additionally, the majority of the BRAF mutant cancers (70\%) grouped into consensus molecular subtype 1 (CMS 1) which was enriched with cancers positive for MSI, methylation, activated immune pathways, and a high propensity for females predicting better prognosis. The next highest proportion of BRAF mutant cancers (17\%) were grouped with CMS4 which consists of Microsatellite Stable (MSS) cancers with upregulation of genes involved in Epithelial-to-Mesenchymal Transition (EMT) and worse prognosis [31]

Also, Barras et al., [32] divided BRAF mutant cancers into two distinct molecular entities (BM1 and BM2) and suggested that BRAF V600E mutant patients should not be considered as having a unique biology. This heterogeneity of BRAF V600E mutant cases might explain our results.

This study also didn't detect any statistical survival difference regarding presence or absence of BRAF V600E mutation similar to other studies $[22,30,34]$

Contradictory, other studies demonstrated strong correlation of BRAF V600E mutated CRC cases with shorter overall survival $[\mathbf{1 6 , 3 3 ]}$. 
Dicrepancy between this study and other studies seems to be because of association between BRAF V600E mutation (a poor prognostic factor) with mismatch repair deficiency (a good prognostic factor) through the somatic hypermethylation pathway [35].

However, further studies with larger sample size and longer follow-up duration are needed to better understand the prognostic role of BRAF V600E protein expression in CRC, which would aid in determination of new therapeutic modalities and prognosis of patients.

\section{References}

1- MOKHTAR N., SALAMA A., BADAWY O., KHORSHED E., MOHAMED G., IBRAHIM M. and ABDELAZIM H.: Cancer Pathology Registry, in Cancer Pathology Registry 2000-2011, Editor: Egypt, p. 32-5, 2016.

2- SIEGEL R.L., K.D. MILLER and A. JEMAL: Cancer statistics, 2019. CA Cancer J. Clin., 69 (1): p. 7-34, 2019.

3- KWON Y., et al.: Prognosis of stage III colorectal carcinomas with FOLFOX adjuvant chemotherapy can be predicted by molecular subtype. Oncotarget, 2017.

4- FESSLER E., et al.: A multidimensional network approach reveals microRNAs as determinants of the mesenchymal colorectal cancer subtype. Oncogene, 35 (46): p. 602637, 2016.

5- SINICROPE F.A., et al.: Molecular markers identify subtypes of stage III colon cancer associated with patient outcomes. Gastroenterology, 148 (1): p. 88-99, 2015.

6- SIDERIS M. and PAPAGRIGORIADIS S.: Molecular biomarkers and classification models in the evaluation of the prognosis of colorectal cancer. Anticancer Res., 34 (5): p. 2061-8, 2014

7- HUTCHINS G., et al.: Value of mismatch repair, KRAS, and BRAF mutations in predicting recurrence and benefits from chemotherapy in colorectal cancer. J. Clin. Oncol., 29 (10): p. 1261-70, 2010.

8- COHEN R., et al.: BRAF-Mutated Colorectal Cancer: What Is the Optimal Strategy for Treatment? Curr. Treat. Options Oncol., 18 (2): p. 9, 2017.

9- LIEVRE A., BLONS H. and LAURENT-PUIG P.: Oncogenic mutations as predictive factors in colorectal cancer. Oncogene, 29 (21): p. 3033-43, 2010.

10- WANG J., et al.: Clinicopathological Significance of BRAF V600E Mutation in Colorectal Cancer: An Updated Meta-Analysis. Journal of Cancer, 10 (10): p. 2332-41, 2019.

11- FARINA-SARASQUETA A., et al.: The BRAF V600E mutation is an independent prognostic factor for survival in stage II and stage III colon cancer patients. Ann. Oncol., 21 (12): p. 2396-402, 2010.

12- ROTH A.D., et al.: Prognostic role of KRAS and BRAF in stage II and III resected colon cancer: Results of the translational study on the PETACC-3, EORTC 40993, SAKK 60-00 trial. J. Clin. Oncol., 28 (3): p. 466-74, 2010.
13- SOULIERES D., et al.: KRAS mutation testing in the treatment of metastatic colorectal cancer with anti-EGFR therapies. Curr. Oncol., 17 (Suppl 1): p. S31-40, 2010.

14- WEISER M.R.: AJCC 8th Edition: Colorectal Cancer. Annals of Surgical Oncology, 25 (6): p. 1454-5, 2018.

15- MIYAZAKI T., et al.: Mutation and expression of the metastasis suppressor gene KAI1 in esophageal squamous cell carcinoma. Cancer, 89 (5): p. 955-62, 2000.

16- DVORAK K., et al.: Immunohistochemistry with AntiBRAF V600E (VE1) Mouse Monoclonal Antibody is a Sensitive Method for Detection of the BRAF V600E Mutation in Colon Cancer: Evaluation of 120 Cases with and without KRAS Mutation and Literature Review. Pathol. Oncol. Res., 25 (1): p. 349-59, 2019.

17- TRAPP R.D., B. : Basic and clinical biostatistics: New York, United States, McGraw-Hill Education, 2017.

18-RITTERHOUSE L.L. and BARLETTA J.A.: BRAF V600E mutation-specific antibody: A review. Semin. Diagn. Pathol., 32 (5): p. 400-8, 2015.

19- THIEL A., et al.: BRAF mutation in sporadic colorectal cancer and Lynch syndrome. Virchows Arch., 463 (5): p. 613-21, 2013.

20- PITON N., et al.: KRAS and BRAF Mutation Detection: Is Immunohistochemistry a Possible Alternative to Molecular Biology in Colorectal Cancer? Gastroenterol. Res. Pract., 2015: p. 753903, 2015.

21- ADACKAPARA C.A., et al.: Immunohistochemistry using the BRAF V600E mutation-specific monoclonal antibody VE1 is not a useful surrogate for genotyping in colorectal adenocarcinoma. Histopathology, 63 (2): p. 187-93, 2013

22- KANIK P., GAJJAR K. and GHOSH N.: Immunohistochemical Localization of KRAS and BRAF and its Clinical Utility in Patients with Colorectal Cancer. Colorectal Cancer: Open Access, 04, 2018.

23- LASOTA J., et al.: Detection of the BRAF V600E mutation in colon carcinoma: Critical evaluation of the imunohistochemical approach. Am. J. Surg. Pathol., 38 (9): p. 1235-41, 2014.

24- SMEBY J., et al.: CMS-dependent prognostic impact of KRAS and BRAFV600E mutations in primary colorectal cancer. Ann. Oncol., 29 (5): p. 1227-34, 2018.

25- GIR'LDEZ M.D., et al.: MSH6 and MUTYH deficiency is a frequent event in early-onset colorectal cancer. Clin. Cancer Res., 16 (22): p. 5402-13, 2010.

26- KWON J.H., et al.: Utility of BRAF VE1 Immunohistochemistry as a Screening Tool for Colorectal Cancer Harboring BRAF V600E Mutation. J. Pathol. Transl. Med., 52 (3): p. 157-63, 2018.

27- CHEN D., et al.: BRAFV600E mutation and its association with clinicopathological features of colorectal cancer: A systematic review and meta-analysis. PLoS One, 9 (3): p. e90607, 2014.

28- ZHANG Y., et al.: Mps1 is associated with the BRAF (V600E) mutation and predicts poor outcome in patients with colorectal cancer. Oncol Lett., 17 (3): p. 2809-17, 2019. 
29- LI C., et al.: BRAF V600E mutation and its association with clinicopathological features of papillary thyroid cancer: A meta-analysis. J. Clin. Endocrinol. Metab., 97 (12): p. 4559-70, 2012.

30- BOKEMEYER C., et al.: Addition of cetuximab to chemotherapy as first-line treatment for KRAS wild-type metastatic colorectal cancer: Pooled analysis of the CRYSTAL and OPUS randomised clinical trials. Eur. J. Cancer, 48 (10): p. 1466-75, 2012.

31- GUINNEY J., et al.: The consensus molecular subtypes of colorectal cancer. Nat. Med., 21 (11): p. 1350-6, 2015.

32- BARRAS D., et al.: BRAF V600E Mutant Colorectal
Cancer Subtypes Based on Gene Expression. Clin. Cancer Res., 23 (1): p. 104-15, 2017.

33- KOPEREK O., et al.: Immunohistochemical detection of the BRAF V600E-mutated protein in papillary thyroid carcinoma. Am. J. Surg. Pathol., 36 (6): p. 844-50, 2012.

34- BARAULT L., et al.: Hypermethylator phenotype in sporadic colon cancer: Study on a population-based series of 582 cases. Cancer Res., 68 (20): p. 8541-6, 2008.

35- TOON C.W., et al.: BRAFV600E immunohistochemistry in conjunction with mismatch repair status predicts survival in patients with colorectal cancer. Modern Pathology, 27 (5): p. 644-50, 2014.

\section{الآهمية الإكلينيكية لطفرة بى راف فى +. .7 الى الهير

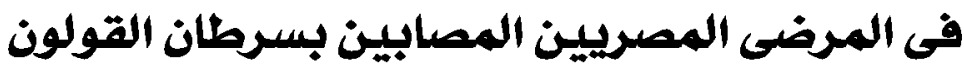

في مصر، هناك زيادة سريعة فى معدل الإصابة بسرطان القولون مع تاريخ مرضى آكثر عدوانية إضافة إلى حدوثه في عمر مبكر نسبياً

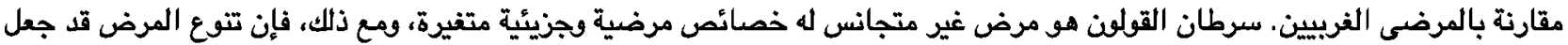

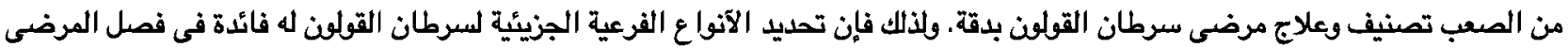

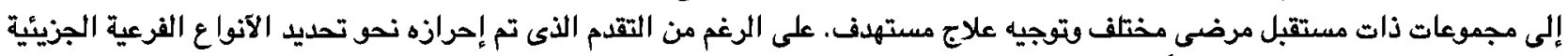

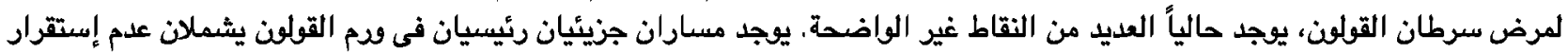
السواتل الصغرى وعلدم الإستقرار الجينى.

تهدف هذه الدراسة إلى دراسة العلاقة بين وجود طفرة بى راف فى . .7 ايى فى المرضى المصريين المصابين بسرطان القولون مع

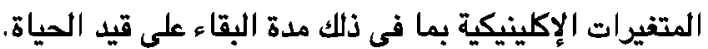

تم إجراء هذه الدراسة من خلال التعاون بين قسم علم الآمراض وقسم الآودام والطب النوصى، كلية الطب، جامعة المنوفية خلال الفترة بين

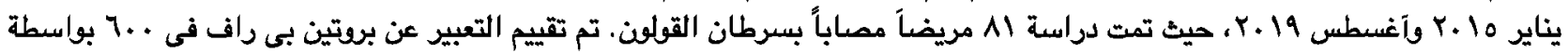

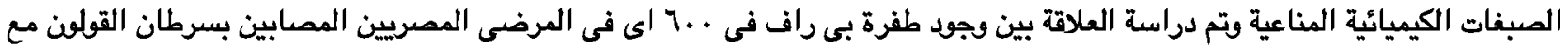
المتغيرات الإكلينيكية بما فى ذلك مدة البقاء على قيد الحياة.

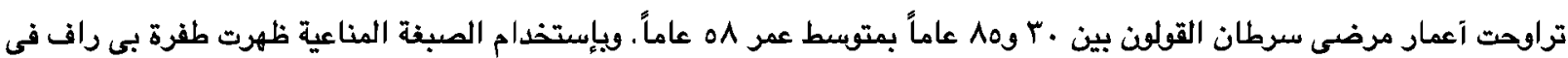

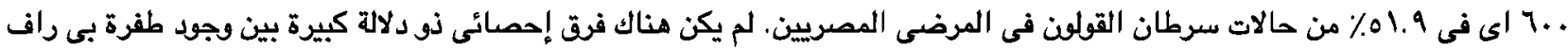

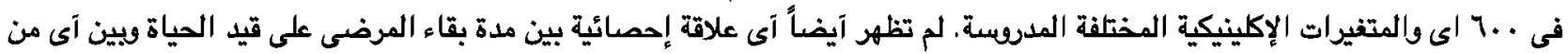
العوامل الإكلينيكية والمرضية المدروسة. المينة

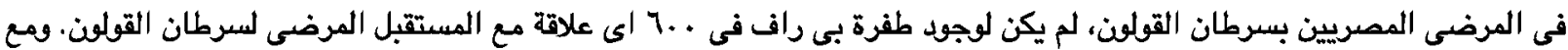

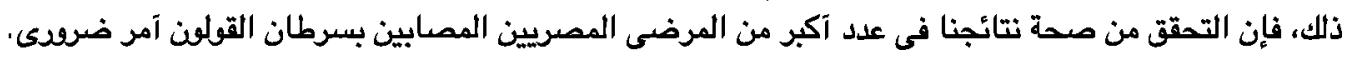

